UDK $316.35: 351$

DOI: $10.21564 / 2075-7190.39 .151164$

\author{
Lindsey Jason Royce, Ph.D., Professor, Head of Department of Political \\ Science St. Cloud State University, St. Cloud, USA \\ e-mail: jrlindsey@stcloudstate.edu \\ ORCID ID: 0000-0002-1363-8850
}

\title{
THE ROOTS OF TRUMPISM
}

The author in the article examines the historical roots and economic and social reasons for the coming to power of the unconventional representative of the US Republican Party, multimillionaire Donald Trump. Trump's phenomenon is interpreted by the author as an American form of revanchism, as revenge for the past, in which the United States lost its positions in the development of the national economy and social sphere. The main characteristics and motivational aspects of the voting of the typical voter D. Trump (white middle-aged men) are revealed. The loss of privileges and economic and social status for whites in the outsider states is seen as the main revanchist motive for supporting L. Trump's electoral core. Parallels are drawn between the phenomenon of the right-wing politician in France, M. Lipin and D. Trump, which in many respects repeats the ideological vector of the French nationalists. The exploitation of patriotic virtue and intense xenophobia are common features of the campaigns of $M$. Le Pen and D. Trump. The first year of the reign of US President D. Trump and the policy of American revanchism with its close ties with dissatisfied whites provoked the grow th of protest moods and extremist groups. The author concludes that President Trump and trampism are not a new or unprecedented political phenomenon in the United States. Trumpism is the result of the activity of an opportunistic candidate who uses in the classic revanchist context the fears of his supporters who face profound social changes.

Key words: Trump, trampism, revanchism, election campaign, democracy, voters.

Formulation of the problem. Commentary on the Trump administration tends toward superlatives like unprecedented, never before seen, and untraditional. However, Trump's successful political campaign looks much less unique if we view Trump's politics as an American form of revanchism. Revanchist regimes and ideologies seek to revenge a past wrong. The original French revanchists were known for being obsessed with winning back territory lost to Prussia in 1871 . Common to all of these movements and governments beyond France is the attempt to force the return of lost status. Trumpism can be read as a white American variation of this ideology.

What is the loss that drove Trump supporters to rally to his unorthodox campaign? The spark for Trump's supporters is a sense of loss tied to the diminishment of (C) Lindsey Jason Royce, 2018 
white supremacy inside the United States and the relative decline of American power in international affairs. Though Trump's core supporters would be the most likely to argue against the whole idea of white privilege, it is the slow erosion of this privilege that stokes this American form of revanchism. The sense of America's decline abroad also lies behind the Trump administrations very public, and economically unorthodox trade policies.

Analysis of actual research. The analysis of President D. Thrump's policy and its historical and ideological basis was carried out by many researchers, among which Arlie Russell Hochschild, Elizabeth Harris, Frederick Brown, Ian Urbina, James Homann, Jean Baudrillard, Kirk Johnson, Loic Wacquant, Diana Mutz, etc.

The purpose of the paper is to show the historical roots and ideological basis of trampism as a natural phenomenon of modern American politics.

Presenting main material. On this point it is important to emphasize that initial analysis of the 2016 election assumed that whites voted for the Trump Campaign for economic reasons. The narrative for this explanation of Trump's success was that unemployed and underemployed white voters in America's rust belt supported Trump out of economic desperation. However, this narrative has been contradicted by subsequent polling and academic studies. The fear driving support for Trump was less about economic anxiety and more about a loss of «status» [3, p.1]. As the political scientist Diana C. Mutz summarizes in her study of the election, «Both growing domestic racial diversity and globalization contributed to a sense that white Americans are under siege by these engines of change» [8]. This perceived sense of threat provided much more explanatory power in her analysis of voting patterns in 2016 compared to claims that Trump supporters were driven by economic concerns.

Is the comparison of Trump's rhetoric and support to French revanchism too farfetched? The plausibility of this connection can be seen in the appearance by Marion Le Pen at the influential CPAC meeting, (a conservative group allied with the Republican party), in February 2018. The compatibility of a wide gathering of conservative Trump supporters with a representative of France's National Front shows the similarity between Trump's American revanchism and the original tradition from France.Consider Frederick Brown's description of the critics of Boulanger's flavor of revanchism. Boulanger's contemporary Jules Ferry wrote with alarm about the rise of this movement: «What distressed him [Ferry] was not nationalist sentiment per se but the tribal character of Boulangist nationalism, its Robespierrian exploitation of patriotic virtue, its intense xenophobia, its spurning of individual judgment and quasi-religious allegiance to its leader, its clamorous irrationalism» [2, p. 42-43]. Sadly, we can see much of the Trump movement's tone in this description from the past. These parallels include the exploitation of patriotism and the irrational support for the leader, even when he is exposed, repeatedly, for lying to his followers. 
There are other striking similarities. Historically, the French revanchists turned to conspiracy explanations as to why the catastrophe of France's 1871 defeat happened. They sought to explain France's loss to Prussia as due to internal rottenness and traitors. Both of these imagined problems were attributed to a decline in French patriotism. In response, the revanchists became hyper conformists about therole of the Church in France and in culturally defending (Frenchness». They enthusiastically gushed over nostalgia about the past, for a mythological France that never was.

Trump's support is very similar in its embrace of what had been viewed in America as conspiracy theories. In a wide study of American conspiracy theories, Uscinski and Parent found that: «Conspiracy theories can undermine the legitimacy and efficacy of government policy, and sometimes lead to violence». On the other hand: «conspiracy theories are essentially alarm systems and coping mechanisms to help deal with foreign threat and domestic power centers. Thus, they tend to resonate when groups are suffering from loss, weakness, or disunity. But nothing fails like success, and ascending groups trigger dynamics that check and eventually reverse the advance of conspiracy theories». Their overall conclusion is that, «In short, successful conspiracy theories conform to a strategic logic based on threat perception». This diagnosis about the role of conspiracy and who it appeals to fits well with research on Trump supporters. Individuals who have a sense of loss or a sense of threat are more likely to turn to conspiracy theories for an explanation of their situation.

Baudrillard used the term, "hyperconformity» to describe what is often an emotional reaction but one that has political resonance» [1]. Confronted with evidence that disproves key aspects of a political ideology, the individual sometimes reacts by irrationally reasserting the absolute truth of his initial position. For Baudrillard, hyperconformity is a form of extreme non-participation where an audience tunes out from the debates of politics and instead relentlessly doubles down on its commitment to politicians and positions that are held in an inviolability. Baudrillard argues that this dynamic makes hyperconformity difficult to challenge because it is non-participation disguised as extreme individual commitment. Just as with the French revanchists of the past, we see a similar dynamic among Trump's supporters.

For example, arguments among Trump supporters that the correct response in the United States to gun violence is loosening gun regulations even further. Or the contradictory outcomes from dire hard support of Trump's trade policies which, in the contemporary, highly integrated global economy, end up hurting some domestic industries as much as «foreign» trade partners. The broad commitment to these positions rather than more subtle policy discussions is reminiscent of the hyperconformity of the original French revanchists. 
How do we define the beginning of sucha broad ideological movement? In the case of the rise of Donald Trump's flavor of revanchism, the origins of its support must be traced back to the end of the Cold War. This context is important because it reveals two important points about the rise of Donald Trump. First, Trump is not an astute political entrepreneur. His presidential campaign does not reflect a successful new political coalition put together through advocacy for particular policies. Instead, Trump is better understood as an opportunist who crucially was (and remains) willing to ally with elements that the traditional political class rejects. Second, this context reveals how Trump's revanchist administration could emerge after the symbolic progress of the Obama years. This question occurs again and again in public commentary about Trump. Many find it difficult to explain how this ideological turn can be explained. By studying the Trump administration and its supporters through the lens of revanchism, Trump's success can be explained as a reaction from the areas of American society that felt a «loss» during the Obama years.

The fact that Trump lifted Reagan's campaign motto, «Make America Great Again», for his own is more relevant than many realize. In the 1980's Ronald Reagan and his political advisers were able to rebuild American patriotism and nationalism by drawing upon nostalgia and contemporary threats. They looked back to the United States of World War II with its clear purpose and moral duty while Reagan also asserted the need to challenge Soviet power in the world. From this foundation, the Republican party was able to rebuild its image after the Watergate debacle and create an ideology that appealed to a broad audience in the United States. Free of complication, this basic ideology of a strong America, continuing to pursue the heroic mission of the 1940's, was easy for many to accept.

Yet, the appeal of this ideology, which to many Americans seemed a restoration of the natural role of the United States, was dependent upon an unperceived global context. The long decade of the 1980's (which extends into the 1990's) marked an Indian summer for the United States' leading position in the world. The long post war expansion of the U. S. economy was disappearing as more nations fully recovered from the conflict ending in 1945 and other developing nations rose to compete in the global economy. This period also marked the zenith of U. S. political and cultural influence as the country's cold war rivals imploded, largely due to their own internal problems. Finally, the U. S. economic model briefly surged thanks to innovations in computer and communications technology.

The longer term, corrosive effects of this ideology were never dreamed of by Reagan and his team. With the collapse of the Soviet Union and the end of the Cold War, this renewed nationalism had no threat to focus upon. Instead, it remained a latent force in the United States through the 1990's that transformed into something more sinister. Other commentators have pointed to similarities between the political 
atmosphere of this period and revanchist France [9, p. 1-20]. The most dramatic example of this internalization of nationalism in the late 1980's and 1990's was the rise in American domestic terrorism with the militia movements. These rabidly nationalist and often racist groups turned inwardly when searching for new enemies. Many of these groups claimed to support the «true American constitution» and cited various enemies at work against it. These enemies ranged from the United Nations to conspiracies within the government of the United States.

What many traditional elites in the Republican party could not have foreseen is how this ideological shift would snowball out of control in the decades to come. After dying down around the turn of the century, the militia movements came back into view after President Obama's election in 2008. An alarming report from the Southern Poverty Law Center in 2009 noted that this «second wave» of the militia movement seemed to be a response to a number of items [10]. One was that it represented a reaction to a return to a more globally aware administration which had not been seen in the US since the Clinton years. Another point was that much of the militia movement lost steam in the U. S. at the turn of the century following the election of a very conservative president. Perhaps too, these groups noticeably declined given the burst of American patriotism and unity so prevalent after September 11, 2001.

However, as the Southern Poverty Law Center also noted in its report, this new, second wave of militia activity bore noticeable differences from the 1990's. Prominently, the racism found in these groups in the 1990's seemed even more pronounced given the election of an African American President. Although present in the 1990's movement, this racism became even more easily transferred onto the Federal government headed by President Obama. Another worrying difference, compared to the 1990's, was the ability of some militia topics and conspiracies to become mainstreamed through conservative media.

Other ominous trends in this nationalist surge can be seen in attitudes toward immigration. The issue of illegal immigration to the United States became an ideological fault line. Although discussed in economic terms when debated in «respectable» quarters, at the grassroots level this debate quickly acquired racial and nationalistic tinges. One mysterious group, «Concerned Citizens of the United States», took upon itself the duty of anonymously sending a list of 1,300 suspected illegal immigrants in Utah to various law enforcement agencies and media organizations. The list even included what it claimed were the due dates of expectant mothers from this group and urged immediate deportation (so that their children would not become U. S. citizens due to being born on U. S. territory) [7, p. 1].

The popularity of this new nativism ideological strain became visible in the first decade of the new century as local politicians began to propose and pass various English only ordinances. Many of these ordinances required local official or 
«public» business to be conducted in English and banned spending on translation services. Ironically, these ordinances appeared in many municipalities by 2010 that had never had an incident that required translation services and lacked any local ethnic community that preferred another language. Instead, local political entrepreneurs were exploiting the fears of local communities for immediate support. On the other hand, in some areas of the country, these ordinances appeared in towns with sizable Latino or immigrant communities. In these cases, the support of such measures by local politicians was more ominous since it reflected a stark political calculation. In effect, that power was more likely to be attained by appealing to a «base» of local white votersrather than the broader community.

Other signs of this ugly nativism could be seen in the anti-Muslim feeling and Islamophobia exploited by the right. One of the more extreme examples was a state constitutional amendment referendum added to the ballot in Oklahoma in the 2010 midterm elections. This referendum, which passed with more than 70 percent of the vote, barred judges in the state from considering Sharia law in cases before them. Of course this particular state has a minuscule Muslim population and most scholars argued that the 1st Amendment provisions separating church and state would prevent the hypothetical issue of the amendment. Furthermore, after the referendum passed legal scholars pointed out the complications from its vague call to ban consideration of «international law») as well. Nonetheless, members of the state legislature who voted against carrying the referendum forward (mostly Democrats) were vilified by opponents in the election as supporting the Islamization of the United States

However, the most shocking evidence for this new nationalism in American politics was the reaction to President Obama from the right. Despite their seeming implausibility, conspiracy theories of how he was not a «real» American persisted throughout his presidency. One set of these odd claims was about how Obama did not qualify as a «natural born citizen» under the Constitution and thus was not eligible for the office of President. The fact that the President was born in an American state (Hawaii) and that his mother was an American citizen (from Kansas) could not dispel this argument from the right. Extraordinary attempts to refute these arguments, such as publishing the President's birth certificate, failed to cut through this odd rhetoric.

More disturbing than this crankish trend, was a deeper thread about identity and President Obama. The idea that President Obama was actually a Muslim became widely accepted among the public. A survey conducted by the Pew Research Centre in August, 2010 found that $18 \%$ of the respondents thought Obama was really a Muslim. Although respectable figures on the right and in the Republican party distanced themselves from these attacks, second tier right wing media outlets continued to promote them. 
The explanation for these outlandish claims lies in the revanchist turn of American politics. Given Obama's support for many causes that the right rejected, many right-wingindividuals made sense of this by concluding that Obama was the "other». If Obama supported immigration reforms that the right opposed, then this became seen as proof that he was illegal. If Obama supported a friendlier approach to the Muslim world in an attempt to battle the ideology of extremism, then many on the right saw this as evidence that he was secretly, «one of them».

Another target for this ideology was the gay community. While many Republicans on the national stage avoided direct appeals to homophobia, the issue of «same sex» marriage provided them with a more innocuous language of anti-gay sentiment. Little restraint however was to be found in other areas of the right. The second-tier right wing press on the internet and right-wing organizations through direct mail, often attempted to energize voters with conspiratorial warnings about the "gay agenda». Sadly, by the end of the first decade in the 2000's playing the homophobia card became a tactical choice for some candidates. For example, Carl Paladino attempted to revive his embattled campaign for governor of New York with a blunt (values»s speech filled with homophobic remarks [4, p. 17]. Paladino had won the Republican nomination as an outsider Tea Party candidate and the rhetoric of this speech aimed at maintaining a certain narrative about him. This narrative attempted to cast Paladino as the voice of the rest of the state, outside of liberal New York City. The extent to which political ideology in the United States was using identity as a marker can be seen in his efforts to prove he was a conservative by making outrageous remarks about Muslims and the Gay community.

The trickle-down effect of this polarization to the level of the citizenry laid a foundation for the Trump campaign to exploit later. As early as 2010, the midterm electionssaw a backlash to Obama's broad win in 2008 with complaints surfacing of intimidation at the polls [12, p.8]. These complaints followed calls by Tea Party supporters to police the polls, claiming that vote fraud was rampant. Some of the ideas for this polling oversight that bubbled up from below was in blatant contradiction to the landmark 1965 Voting Rights Act. That earlier legislation had broken the intimidation of African American voters in the South East by the old white power structure there. Now in 2010 there were populist calls for a campaign to make sure illegal immigrants and other shady individuals did not undermine the election. Fortunately, most of these talked about schemes fizzled out in the overall success of the right that year.

The other oddity in these ideological divisions was the very differing myths of the Republic one found from left to right. For conservatives, the original American Republic became an idealized past to return to. From this perspective, the Constitution was seen as an ideal, almost divine document, that contained everything the contemporary political system needed. Flaws in the politics of today could be 
attributed to deviations from this original script. For liberals, the broader history of the United States was important. From this perspective, the Constitution contained flaws, like its original acceptance of slavery, that were rectified over a long period of time. These improvements came through a combination of the development of the Republic and the sacrifices and political efforts of the citizenry, especially minorities as they sought inclusion.

Unfortunately, these abstract «cultural wars» have led to very concrete effects. From these somewhat obscure dramas of the early 2000's we see the logical outcome of a national political candidate that openly embraces this ideological turn.Much of the «unpredictability» that longtime Washington insiders associate with President Trump can be attributed to his fears of alienating his most driven ideological supporters. For example, in February of 2018, in an effort to obtain everything he wanted on an immigration bill, President Trump shocked Senators from both parties by rejecting a bill that would have narrowly passed with much of what he wanted [6]. The fact that the President rejected the usual method of politics to achieve a victory, because of an unrealistic drive to achieve $100 \%$ of what he demanded, was a signal to many that the most extreme ideological demands were now driving the administration. And more than delivering on any sort of policy pledges, the administration is focused on its ideological claims.

If we turn to look at the «base» that was so receptive to Trump's message, then we find a large white population embracing its own call to identity politics. There is much political science commentary that describes the current Democratic Party in the US as an alliance of many groups including minorities. From this perspective, Trump has given voice to many whites in the US who have, with varying degrees of awareness, embraced the Republican party as the political formation allied with their identity [5].

On an even larger scale, some observers draw a direct line between the effects of global capitalism and the rise of populist movements in various countries, including the Trump phenomenon in the United States. From this broader perspective, the ideological shape of Trumpism emerges. It is a classic revanchist regime that exploits nostalgia for a mythical past. The revanchist element is not over lost territory but represents a white America that feels it has lost its status. It is also a reaction to perceptions of a loss of American influence in the world. At home, this is felt less technologically skilled workers in a shifted economy that has, in many ways, lost to its global competition.

This nostalgia is combined with unrealistic assertions about the contemporary power and influence of the United States. Rather than proposing bold changes to deal with pressing 21 st century problems, it promises that a return to the tried and true ways of doing things is all that is needed. The coded and not so coded messages 
of maintaining white supremacy within Trump's campaigning cannot be ignored either. They point to a past that has been substantively transformed by the country's changing demographics and the shift in attitudes toward difference amongthe young. The symbolic marker for this change was President Obama's time in office.

However, this social progress also triggered a reaction. In its 2017 report on hate groups in the U. S., the Southern Poverty Law Center found an increase of $4 \%$ in the number of active groups compared to 2016. They also found an increase in the number of so called «patriot groups» in the U. S. In reaction, the Center also noted a rise in so called Black Nationalist groups. Thus, the first year of Trump's administration, and the politics of this American revanchism, with its close ties to dissatisfied whites, triggered a growth in extremist groups.

Conclusions. This increase in hate groups in the U. S. shows the fringe movement of the coalition that Trump assembled in 2016. Despite widespread speculation in the U. S. about social progress in the Obama years, Trump's successful campaign channeled less visible resentment. Some commentators have argued that race and revanchist tendencies have been visible for some time in the US [14, p. 74-80]. From this perspective, President Trump and Trumpism is not a new or unprecedented political phenomenon in the United States. Instead, Trumpism is a result of an opportunist candidate exploiting, in classic revanchist fashion, the fears of supporters who face profound social change.

\section{REFERENCES}

1. Baudrillard, J. (1987). In the Shadow of the Silent Majorities. New York: Semiotext(e).

2. Brown, F. (2014). The Embrace of Unreason France 1914-1940. New York: Anchor Books.

3. Chokshi, N. (2018, April 24). Trump Voters Driven by Fear of Losing Status, Not Economix Anxiety, Study Finds. The New York Times, p. Al.

4. Harris, E. (2010, October 11). Paladino Laces Speech with Antigay Remarks. The New York Times, p. A17.

5. Hochschild, A. R. (2018). Strangers in Their Own Land. New York: The New Press.

6. Homann, J. (2018, February 16). Immigration failure shows the ideologues are ascendant in the Trump White House. The Washington Post.

7. Johnson, K. (2010, July 15). Immigrant List Sets Off Fears. The New York Times, p. A1.

8. Mutz, D. C. (2018). Status threat, not economic hardship, explains the 2016 presidential vote. Proceedings of the National Academy of Sciences: 201718155.

9. Smith, N. (1998). Giuliani Time: the Revanchist 1990s. Social Text, Vol. 57, pp. 1-20.

10. Southern Poverty Law Center. (2009). The Second Wave: The Return of the Militias. Retrieved from https://www.splcenter.org/20090801/second-wave-return-militias. 
11. Southern Poverty Law Center. (2018). The year in Hate: Trump buoyed white supremacists in 2017, sparking backlash among black nationalist. Retrieved from https://www.splcenter.org/news/2018/02/20/year-hate-trump-buoyed-whitesupremacists-2017-sparking-backlash-among-black-nationalist.

12. Urbina, I. (2010, November 3). Reports of Intimidation and Problems Surface at Polls. The New York Times, p. P8.

13. Uscinski, Y. (2014). American Conspiracy Theories. New York: Oxford University Press.

14. Wacquant, L. (2010). Class, Race, and Hyperincarceration in Revanchist America. Daedalus, Vol. 139, No.3, pp.74-90.

Линдси Джсейсон Ройс, доктор философии, профессор, заведующий кафедры политологии Сент-Клаудского Университета, Сент-Клауд, США

\section{КОРНИ ТРАМПИЗМА}

Автор в статье рассматривает исторические корни, экономические и соииальные причины прихода к власти нетрадиционного представителя Республиканской партии США, мультимиллионера Дональда Трампа. Феномен Трампа автор трактует как американскую форму реваниизма, как месть за проилое, в котором США утратили свои позиции в развитии национальной экономики и сочиальной сферы. Раскрываются основные характеристики и мотивационные аспекты голосования типичного избирателя Д. Трампа (белого мужчины средних лет). Утрата привилегий и экономико-сочиального статуса для бельх в итатах-аутсайдерах рассматривается как главный реваниисткий мотив поддержки электоральным ядром Д. Трампа. Проводятся параллели между феноменом правого политика во Франчии М. Ле Пен и Д. Трампом, который во многом повторяет идеологический вектор франиузских националистов. Эксплуатачия патриотической добродетели и интенсивная ксенофобия - общие черты кампаний М. Ле Пен и Д. Трампа. Первый год правления президента США Д. Трампа и политика американского реваншизма с его тесными связями с неудовлетворенными белыми спровочировали рост протестных настроений и экстремистских групп. Автор делает вывод, что президент Трамп и трампизм не являются новым или беспречедентным политическим явлением в Соединенных Штатах. Трампизм является результатом деятельности оппортунистического кандидата, использующего в классическом реваниистском контексте страхи своих сторонников, которые сталкиваются с глубокими сочиальными изменениями.

Ключевые слова: Трамп, трампизм, реваниизм, избирательная кампания, демократия, избиратели. 
Ліндсі Дюсейсон Ройс, доктор філософії, професор, завідувач кафедри політології Сент-Клаудсъкого Університету, Сент-Клауд, США

\section{КОРІННЯ ТРАМПІЗМУ}

Постановка проблеми. Коментарі до правління адміністрачії президента Д. Трампа мають тендениію до завищення оиінок, яких ніколи раніие не було, і які поруиують традицію. Однак иее не зовсім так, адже подібні феномени вже мали місие в американській та франиузькій історій.

Аналіз актуальних досліджень. Аналіз політики Президента Д. Трампа та ї історичної та ідеологічної основи проводився багатьма дослідниками, серед яких Арлі Рассел Хохиильд, Елізабет Гарріс, Фредерік Браун, Ян Урбіна, Дэсеймс Хомани, Жан Бодріяр, Кірк Дюсонсон, Лойк Ваккан, Діана Мути тощо.

Мета статті - показати історичне коріння та ідеологічні основи трампізму як природного явища сучасної американської політики.

Виклад основних положень. Автор статті розглядас історичні основи та економічні й сочіальні причини приходу до влади нетрадиійного представника Республіканської партії США, мультиміліонера Дональда Трампа. Феномен Трампа автор трактус як американську форму реваниизму, як помсту за минуле, в якому США втратили свої позиціїу розвитку національної економіки та сочіальнӧ̈ сфери. Успішна політична кампанія Д. Трампа виглядас набагато мени унікальною, якцо розглядати політику Д. Трампа як американську форму ревапиизму. Розкриваюоться основні характеристики та мотиваційні аспекти голосування типового вибория Д. Трампа (білого чоловіка середніх років). Втрата привілеїв та економіко-сочіального статусу для білих у итатах-аутсайдерах розглядаються як головний реваниистський мотив підтримки електорального ядра Д. Трампа. Проводяться паралелі між феноменом правого політика у Франції М. Ле Пен і Д. Трампом, який багато в чому повторюс ідеологічний вектор франиуьких націоналістів. Експлуатація патріотичнӧ̈ доброчинності та інтенсивна ксенофобія с спільними рисами кампаній М Ле Пен та Д. Трампа. Підтримка Д. Трампа дуже схожа на те, що розглядалося в Америці як теорія змови. У иирокому вивченні американських теорій змови Усинські встановив, що «теорії змови можуть підірвати легітимність і ефективність дерлсавної політики, а іноді і призвести до насильства». 3 іниого боку, «теорії змови - це, по суті, система сигналізації та механізми подолания, щоб допомогти впоратися з іноземною загрозою і центрами внутрішньої влади».

Ця ностальгія посднусться з нереалістичними тверджсеннями про сучасну силу і вплив Сполучених Штатів. Замість того, щоб пропонувати сміливі зміни для вирімення нагальних проблем 21 століття, Д. Трамп обіџяс, щзо повернення до перевірених та істинних способів вчинення дій-все, що необхідно. Не можна існорувати закодовані і не настільки закодовані повідомлення про збереження переваги білої раси в кампанії Д. Трампа. Вони вказують на минуле, яке істотно трансформувалося через зміни демографії крайни $і$ зміни ставлення до відмінностей серед молоді. 
Символічним маркером чієї зміни був час перебування при владі президента Обами. Однак ией сочіальний прогрес також викликав реакиію. Периий рік правління президента США Д. Трампа і політика американського реваниизму з його тісними зв 'язками з невдоволеними білими викликали зростання протестних настроӥв та екстремістських груп. У свойй доповіді про групи ненависті в США за 2017 рік Південний чентр боротьби з бідністю виявив збільиення числа активних груп на $4 \%$ у порівнянні з 2016 роком. Він також виявие збільшення числа так званих «патріотичних груп» в США. У відповідь на че Центр також відзначив зростання так званих чорних науіоналістичних груп. Отже, президент Д. Трамп і трампізм не є новим або безпречедентним політичним явищем для Сполучених Штатів.

Робиться висновок, ио трампізм є результатом діяльності опортуністичного кандидата, цо використовуе в класичному реваниистському контексті жахи свойх прихильників, які стикаються з глибокими сочіальними змінами.

Ключові слова: Трамп, трампізм, реваниизм, виборча кампанія, демократія, вибориі.

\section{soxes}

